\title{
Synthesis of Azole-containing Piperazine Derivatives and Evaluation of their Antibacterial, Antifungal and Cytotoxic Activities
}

\author{
Lin-Ling Gan, ${ }^{\dagger+}$ Bo Fang, ${ }^{\dagger}$ and Cheng-He Zhou ${ }^{\dagger, *}$ \\ ${ }^{\dagger}$ Laboratory of Bioorganic \& Medicinal Chemistry, School of Chemistry and Chemical Engineering, Southwest University, \\ Chongqing, P. R. China.*E-mail: zhouch@swu.edu.cn \\ ${ }^{\$}$ School of Pharmaceutical Sciences, Southwest University, Chongqing, P. R. China \\ Received May 17, 2010, Accepted October 11, 2010
}

\begin{abstract}
A series of azole-containing piperazine derivatives have been designed and synthesized. The obtained compounds were investigated in vitro for their antibacterial, antifungal and cytotoxic activities. The preliminary results showed that most compounds exhibited moderate to significant antibacterial and antifungal activities in vitro. 1-(4-((4-chlorophenyl) (phenyl)methyl)piperazin-1-yl)-2-(1H-imidazol-1-yl)ethanone and 1-(4-((4-Chlorophenyl)(phenyl)methyl)piperazin-1yl)-2-(2-phenyl-1 $H$-imidazol-1-yl)ethanone gave remarkable and broad-spectrum antimicrobial efficacy against all tested strains with MIC values ranging from 3.1 to $25 \mu \mathrm{g} / \mathrm{mL}$, and exhibited comparable activities to the standard drugs chloramphenicol and fluconazole in clinic. Moreover, 2-((4-((4-chlorophenyl)(phenyl)methyl)piperazin-1-yl)methyl)$1 H$-benzo[d]imidazole was found to be the most effective in vitro against the PC-3 cell line, reaching growth inhibition values $(36.4,60.1$ and $76.5 \%)$ for each tested concentration: $25 \mu \mathrm{M}, 50 \mu \mathrm{M}$ and $100 \mu \mathrm{M}$ in dose-dependent manner. The results also showed that the azole ring had noticeable effect on their antimicrobial and cytotoxic activities, and imidazole and benzimidazole moiety were much more favourable to biological activity than 1,2,4-triazole.
\end{abstract}

Key Words: Piperazine, Imidazole, Antibacterial, Antifungal, Cytotoxicity

\section{Introduction}

The number of patients suffering from cancer diseases or some life-threatening infections has continued to rise rapidly with years, though great progresses have been made in diagnosis, prevention, therapy and medicinal chemistry. Especially, the alarming rates of emerging drug resistant strains and cancer cell lines, leading to failure in therapy, continue to serve as impetus for the development of novel and more effective antimicrobial and anticancer agents. $^{1-3}$

The piperazine-based research has attracted considerable attention in recent years. Piperazine and substituted piperazine nuclei had constituted an attractive pharmacological scaffold present in various potent marketed drugs. The incorporation of piperazine is an important synthetic strategy in drug discovery due to its easy modificability, proper alkality, water solubility, the capacity for the formation of hydrogen bonds and adjustment of molecular physicochemical properties. ${ }^{4,5}$ A broad range of biological active compounds displaying antibacterial, ${ }^{3,6-8}$ antifungal, ${ }^{9,10}$ anticancer, ${ }^{11-13}$ antiparasitic, ${ }^{4,15}$ antihistamin, ${ }^{16}$ psychotolytic, ${ }^{17}$ and antidepressive activities ${ }^{18}$ have been also found to contain this versatile core. In particular, structurally simple 1(1-naphthylmethyl)-piperazine, as the efflux pump inhibitor, could exert positive effect on tetracyclines and ciprofloxacin against their resistant bacteria. ${ }^{19,20}$ Moreover, benzotriazole-based piperazine derivatives and $N, N{ }^{\prime}$-bis(alkyloxymethyl)piperazines had moderate antibacterial and antifungal activities against pathogenic bacterial strains and fungal strains. ${ }^{21,22}$ On the other hand, a novel microtubule depolymerizing piperazine derivative, 1-(5-chloro-2-methoxybenzoyl)-4-(3-chlorophenyl) piperazine, caused inhibition of proliferation of a wide range of cancer cell lines including a multidrug-resistant cell line, with an

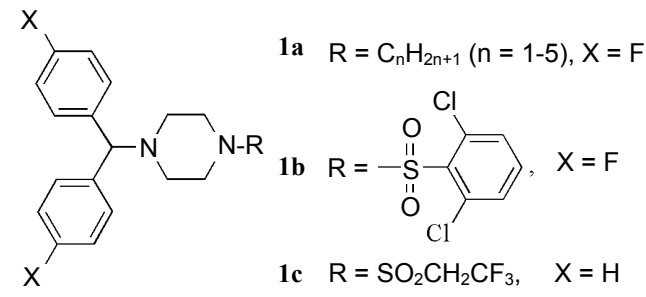

Figure 1. Structures of some biological active piperazine derivatives.

average $\mathrm{IC}_{50}$ of $85 \mathrm{nM}^{23}$ These results once again highlighted that piperazine core was an important backbone and prompted us to design some active molecules with piperazine nucleus.

Several literatures provided evidence that the introduction of such bulky groups like diphenyl could increase antimicrobial activity by enhancing lipophilicity of the molecule, which may result in more penetration into cells. ${ }^{24}$ Thus piperazine derivatives bearing diphenyl substitution at N1 position also have been introduced to design new antibacterial and antifungal agents, though this moiety has wide application in antihistamine like cetirizine, calcium antagonist (flunarizine) etc. Recently, Rangappa et al. ${ }^{25}$ reported the synthesis and in vitro antimicrobial studies of medicinally important novel $\mathrm{N}$-alkyl and $\mathrm{N}$-sulfonyl derivatives of 1-[bis(4-fluorophenyl)-methyl]piperazine 1a and 1b(Figure 1), which demonstrated potent inhibition against representative strains of Gram-positive and Gram-negative bacteria when compared to the standard drug streptomycin. Furthermore, novel 1-benzhydryl piperazine derivative 1c (Figure 1) gave interesting growth inhibitory effects against one normal cell line and four human cancer cell lines for the time period of 24 h. ${ }^{26}$ Consequently, the optimization of diphenyl piperazine 
derivatives may lead to a new route to potential pharmaceutical molecules as antimicrobial and anticancer agents.

It is well-known that azole moieties, such as triazole, imidazole, benzimidazole ring, etc. as important pharmacophores are present extensively in diverse types of drugs in clinical use. ${ }^{27-29}$ More importantly, azole derivatives as antimicrobial agents, especially as antifungal drugs represent a novel emerging major chemical entity. For instance, ketoconazole, itraconazole, fluconazole and its ester prodrug fosfluconazole, posaconazole and ravuconazole are widely used in the treatment of systemic fungal infections, and particularly, miconazole could exhibit remarkable antibacterial activity against MRSA.$^{30}$ On the other hand, the azole compounds also have attracted much attention due to their prominent utilization as antitumor agents. ${ }^{31-33}$ Therefore, these progressive findings about the biological activities of azole derivatives led numerous efforts to develop some azole derivatives as new antimicrobial and anticancer agents.

In view of this and in the continuation of previous researches on synthesis and antimicrobial studies of bioactive heterocycles, ${ }^{34,35}$ it is worthwhile to synthesize new 1-((4-chlorophenyl)(phenyl)methyl) piperazine derivatives bearing various heterocyclic nuclei such as triazole, imidazole, benzimidazole etc. and to evaluate for their antimicrobial activities against $S$. aureus, Methicillin-resistant Staphylococcus aureus (MRSA), B. subtilis, M. luteus, E. coli, P. vulgaris, P. aeruginosa, S. typhi,
S. dysenteriae, C. albicans, $S$. cerevisiae and $A$. fumigatus as well as antitumor activity against human prostatic carcinoma cell (PC-3).

\section{Results and Discussion}

Chemistry. The general route for the synthesis of diphenylattached piperazine derivatives is outlined in Scheme 1. The intermediate 1-((4-chlorophenyl)(phenyl)methyl) piperazine 2 was prepared by a known procedure in three steps, including $\mathrm{NaBH}_{4}$ reduction, chlorination and $\mathrm{N}$-aralkylation from the commercially available (4-chlorophenyl)(phenyl)methanone as starting materials. ${ }^{26}$ The chloride 3 was obtained by the reaction of 2 with a large excess of 1,2-dichloroethane using triethylamine as base. ${ }^{37}$ The reaction of $\mathbf{2}$ with 2-(chloromethyl)oxirane at room temperature without base using anhydrous ethanol as solvent produced another important chloride $\mathbf{4}$ with the yield of $40 \%{ }^{38}$ The key intermediate 5 was obtained in $45 \%$ yield by the $N-4$ acylation of 2 with chloroacetyl chloride in the presence of triethylamine in ice-bath. ${ }^{39}$ The subsequent treatment of $\mathbf{3}, \mathbf{4}$ and $\mathbf{5}$ with a series of azole compounds such as triazole, imidazole, substituted imidazole and benzimidazole etc in the presence of a mild base, anhydrous $\mathrm{K}_{2} \mathrm{CO}_{3}$ gave the azole 1-((4chlorophenyl)(phenyl)methyl) piperazine derivatives 7, 8a-b 9a-f, 10a-c and 11 in good yields after chromatographic purifica-

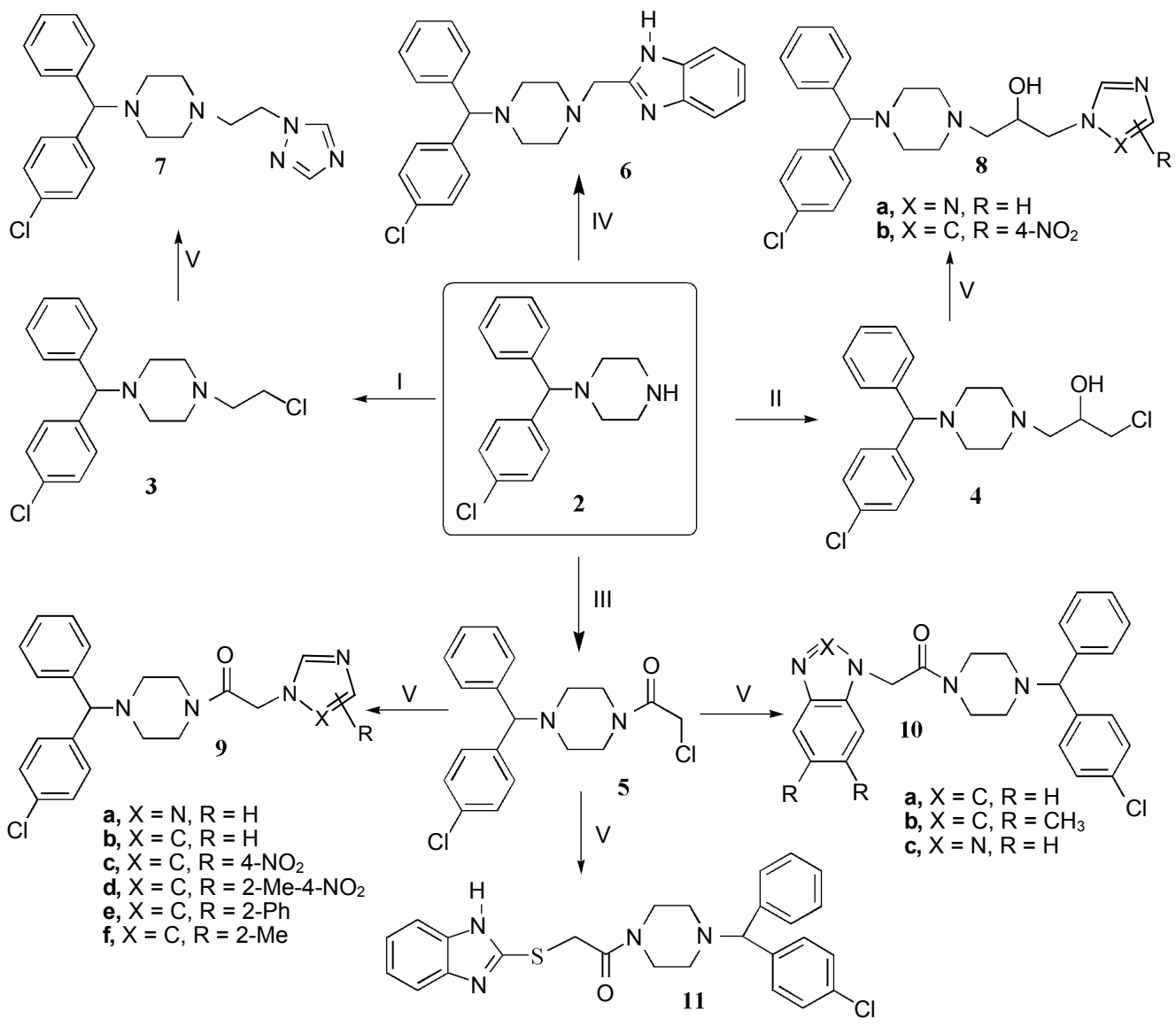

Scheme 1. Synthetic route of azole-containing piperazine derivatives 6-11. Reagents and conditions: (I) $\mathrm{ClCH}_{2} \mathrm{CH}_{2} \mathrm{Cl}, \mathrm{Et}_{3} \mathrm{~N}$, reflux, $20 \mathrm{~h}$. (II) 2(Chloromethyl)oxirane, $\mathrm{CH}_{3} \mathrm{CH}_{2} \mathrm{OH}$, rt, 24 h. (III) $\mathrm{ClCOCH}_{2} \mathrm{Cl}_{2} \mathrm{CH}_{2} \mathrm{Cl}_{2}, \mathrm{Et}_{3} \mathrm{~N}, 0$ - $5{ }^{\circ} \mathrm{C}, 5 \mathrm{~h}$. (IV) 2-(Chloromethyl)- $1 \mathrm{H}$-benzo[ $\left.d\right]$ imidazole, $\mathrm{CH}_{3} \mathrm{COCH}_{3}$, rt, 12 h. (V) Azoles, $\mathrm{CH}_{3} \mathrm{CN}, 45-70{ }^{\circ} \mathrm{C}$. 
Table 1. Antibacterial activity of compounds 3-11 expressed as MIC $(\mu \mathrm{g} / \mathrm{mL})$

\begin{tabular}{|c|c|c|c|c|c|c|c|c|}
\hline Compd. & S. aureus & MRSA & B. subtilis & M. luteus & E. coli & P. vulgaris & S. typhi & S. dysenteriae \\
\hline 3 & 200 & 200 & 100 & 100 & 400 & 200 & 200 & 200 \\
\hline 4 & 50 & 25 & 50 & 50 & 100 & 100 & 100 & 100 \\
\hline 5 & 25 & 25 & 25 & 25 & 25 & 25 & 50 & 50 \\
\hline 6 & 25 & 25 & 6.2 & 25 & 50 & 25 & 25 & 12.5 \\
\hline 7 & 100 & 100 & 100 & 100 & 200 & 100 & 200 & 100 \\
\hline $8 \mathbf{a}$ & 100 & 100 & 100 & 100 & 200 & 100 & 200 & 100 \\
\hline $8 b$ & 50 & 50 & 50 & 50 & 25 & 25 & 50 & 50 \\
\hline $9 a$ & 200 & 200 & 50 & 100 & 400 & 100 & 100 & 50 \\
\hline $9 b$ & 3.1 & 6.2 & 6.2 & 6.2 & 25 & 12.5 & 12.5 & 6.2 \\
\hline $9 \mathrm{c}$ & 50 & 50 & 25 & 50 & 100 & 50 & 25 & 6.2 \\
\hline 9d & 50 & 50 & 25 & 50 & 200 & 50 & 25 & 6.2 \\
\hline $9 e$ & 6.2 & 12.5 & 12.5 & 6.2 & 25 & 25 & 12.5 & 6.2 \\
\hline $9 f$ & 50 & 50 & 25 & 12.5 & 50 & 25 & 50 & 25 \\
\hline 10a & 25 & 25 & 25 & 25 & 200 & 25 & 25 & 25 \\
\hline $10 \mathrm{~b}$ & 50 & 50 & 25 & 25 & 200 & 50 & 25 & 25 \\
\hline $10 \mathrm{c}$ & $>400$ & $>400$ & $>400$ & $>400$ & $>400$ & $>400$ & $>400$ & $>400$ \\
\hline 11 & $>400$ & $>400$ & $>400$ & $>400$ & $>400$ & $>400$ & $>400$ & $>400$ \\
\hline $\mathbf{C h l} \mathbf{l}^{a}$ & 3.1 & 6.2 & 3.1 & 1.6 & 6.2 & 3.1 & 3.1 & 1.6 \\
\hline
\end{tabular}

chl, chloramphenicol.

Table 2. Antifungal activity of compounds 3-11 expressed as MIC $(\mu \mathrm{g} / \mathrm{mL})$

\begin{tabular}{|c|c|c|c|c|c|c|c|}
\hline Compd. & C. albicans & S. cerevisiae & A. fumigatus & Compd. & C. albicans & S.cerevisiae & A. fumigatus \\
\hline 3 & 200 & 200 & 200 & $9 c$ & 25 & 25 & 50 \\
\hline 4 & 100 & 100 & 100 & 9d & 100 & 25 & 100 \\
\hline 5 & 25 & 25 & 50 & $9 e$ & 12.5 & 3.1 & 25 \\
\hline 6 & 25 & 25 & 50 & 9f & 25 & 25 & 50 \\
\hline 7 & 100 & 100 & 200 & 10a & 25 & 25 & 100 \\
\hline $8 \mathbf{a}$ & 100 & 100 & 200 & $10 \mathrm{~b}$ & 25 & 25 & 100 \\
\hline $8 b$ & 25 & 25 & 50 & $10 \mathrm{c}$ & $>400$ & $>400$ & $>400$ \\
\hline $9 \mathrm{a}$ & 100 & 100 & 100 & 11 & $>400$ & $>400$ & $>400$ \\
\hline $9 b$ & 6.2 & 12.5 & 25 & flu ${ }^{a}$ & 0.8 & 1.6 & 256 \\
\hline
\end{tabular}

${ }^{a}$ flu, fluconazole.

tion on silica gel. Besides, the compound $\mathbf{6}$ was synthesized by direct reaction of intermediate 2 and 2-(chloromethyl)- $1 \mathrm{H}$ benzo $[d]$ imidazole in acetone at room temperature.

In the preparation of intermediate 5 , the reaction was related with the dropwise rate of chloroacetyl chloride. The slow dropwise addition of the chloroacetyl chloride instead of addition at once would increase the yield and decrease the possibility of decomposition. The nucleophilic substitution reactions of the intermediate $\mathbf{4}$ or $\mathbf{5}$ with different azoles were found to depend on the acidity of the azole rings and the reactivity of the intermediates to some extent. The azole rings with stronger acidity (triazole, 4-nitro-imidazole, 2-methyl-5-nitro-imidazole) need shorter reaction time and lower temperature than those with weaker acidity (imidazole, benzimidazole and the electrondonor group substituted imidazole), and compound $\mathbf{5}$ reacted far more readily with azoles than $\mathbf{4}$ under the same conditions. Furthermore, the presence of weak base potassium carbonate rather than strong base such as $\mathrm{NaH}$ in the reaction of compound 5 with imidazole, 2-methyl, 2-phenyl imidazole and benzimidazole gave good yields of title compounds, which made the procedure more convenient and safe.

All the synthesized compounds were confirmed by MS, IR and ${ }^{1} \mathrm{H}$ NMR spectra as well as elemental analyses. The spectral analyses were in accordance with the assigned structures, and all the characterization data were given in the experimental section. The mass spectra showed that compounds 6-11 gave a $[\mathrm{M}]^{+}$or $[\mathrm{M}+\mathrm{Na}]^{+}$peak, in agreement with their molecular formula. Since $\mathrm{NaBH}_{4}$ used for the (4-chlorophenyl)(phenyl)methanone reduction would in no way result in a stereochemical preference on the formation of benzhydrol, ${ }^{40}$ the synthesized piperazine derivatives were racemates, which were confirmed by polarimeter.

Pharmacology. The desired compounds 6-11 and the intermediates 3-5 were provided for their antibacterial and antifungal 


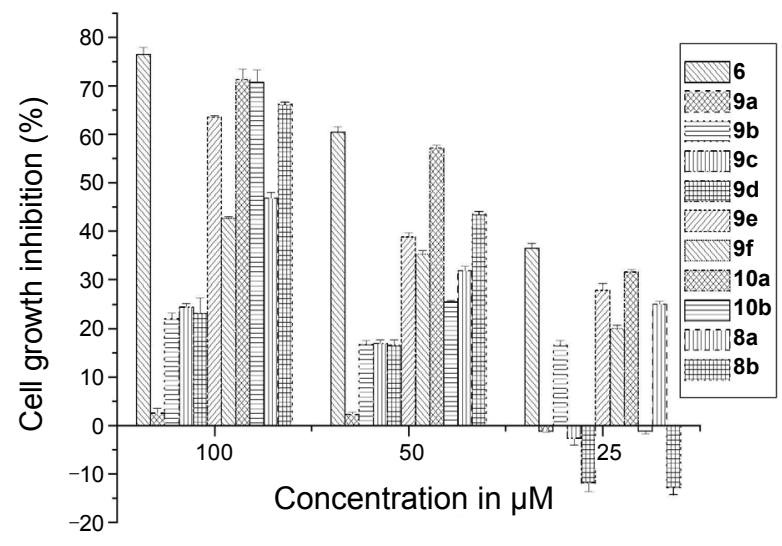

Figure 2. The cytotoxic activities of the tested compounds.

assaying as racemates against Gram positive, Gram negative bacteria and fungi, in comparison with chloramphenicol and fluconazole as standard drugs, and their antimicrobial results were reported as minimal inhibitory concentrations (MICs, $\mu \mathrm{g}$ / $\mathrm{mL}$ ), and were shown in Table 1 and Table 2.

The newly synthesized compounds were also evaluated for their cytotoxic activity towards human tumour cell line PC-3 (human, prostatic carcinoma cell) by MTT assay. Results of each tested agents were reported as the growth inhibition percentage of treated cells when compared to the untreated control ones. The cell growth inhibition rates were summarized in Figure 2.

Antibacterial activity: The antibacterial tests indicated that all the tested compounds were able to inhibit the growth of the selected microorganisms in vitro, whereas the compounds 10c and $\mathbf{1 1}$ were inactive even at the highest tested concentration against both Gram-negative and Gram-positive bacteria. In addition, it turned out that Gram-negative strain E. coli was less sensitive to most azole-containing compounds compared to other tested bacterial strains.

As was seen in Table 1, the three intermediates 3-5 showed weak to moderate antibacterial activities, and the chloride $\mathbf{5}$ with amide linkage, which had been reported as hypocholesteremic agents at the first time in $1968,{ }^{39}$ exhibited best antibacterial activities among the three intermediates 3-5. The replacement of chlorine atom with the different azole rings resulted in variation of the antibacterial activities. It was observed that the heterocyclic moiety had noticeable effect on the antibacterial activities. The biological activities of azole-containing piperazine derivatives decreased as the following orders: imidazole and substituted imidazoles $\mathbf{9 b - f} \geq$ benzimidazoles $\mathbf{6}, \mathbf{1 0 a}$ and 5,6dimethyl-benzimidazole $\mathbf{1 0 b}>$ triazoles 7, 8a and 9a $>$ benzotriazole 10c, 2-thiol benzimidazole 11. These facts suggested that imidazole and benzimidazole residues should have the synergistic effect on biological activities, but the benzotriazole and 2-thiol benzimidazole nucleus may exert negative efficacy on their activities.

For the tested imidazole and its substituted derivatives $9 \mathbf{b - f}$, all of them showed broad antibacterial spectrum. Especially, compounds $9 \mathbf{b}$ and $9 \mathbf{e}$ with imidazole and 2-phenyl imidazole ring, respectively, had the strongest antibacterial activities against pathogenic bacterial strains with the MIC values in the range of $3.1-25 \mu \mathrm{g} / \mathrm{mL}$. Compound $9 \mathrm{~b}$ exhibited significant ac- tivity against $S$. aureus with the MIC value of $3.1 \mu \mathrm{g} / \mathrm{mL}$, which was equivalent to that of chloramphenicol as the reference drug. This compound also revealed good activity against MRSA, $B$. subtilis, M.luteus and $S$. dysenteriae (MIC $=6.2 \mu \mathrm{g} / \mathrm{mL}$ ), as well as moderate activity against $E$. coli, $P$. vulgaris and $S$. typhi, with the MIC values of $25,12.5$ and $12.5 \mu \mathrm{g} / \mathrm{mL}$, respectively. The results suggested that it was the most active compound among the azole-containing piperazine derivatives. Besides, compound 9e also showed excellent activity against $S$. aureus, $M$. luteus and $S$. dysenteriae, and it could effectively inhibit the growth of the three strains at the same concentration of $6.2 \mu \mathrm{g} / \mathrm{mL}$. Meanwhile, this compound also displayed moderate activity against the rest tested strains. On the other hand, other compounds with substitution on imidazole ring, such as 9c with 4- $\mathrm{NO}_{2}, 9 d$ with 2- $\mathrm{CH}_{3}-4-\mathrm{NO}_{2}$, 9f with 2- $\mathrm{CH}_{3}$ group also gave moderate to excellent antibacterial activities with the MIC values ranging from 6.2 to $50 \mu \mathrm{g} / \mathrm{mL}$, but poor activity against $E$. coli. Furthermore, it's noteworthy that the three compounds almost have the same antibacterial potential against Gram positive bacterial strains, whereas they had slight difference on their antibacterial activities against Gram negative bacterial strains. Compound 9f with electron-donor methyl group exhibited best antibacterial activities against the four Gram negative bacterial strains among the three compounds, the next one was the compound 9d with 2$\mathrm{CH}_{3}-5-\mathrm{NO}_{2}$, and the lowest antibacterial activity was the compound $9 \mathrm{c}$ with $4-\mathrm{NO}_{2}$. These results suggested that their antibacterial activities had been ascribed to the nature of the substituents to some extent.

Benzimidazoles bearing derivatives $\mathbf{6}$ and 10a-b gave relatively good activities against most tested bacterial strains with the MIC values ranging from 25 to $100 \mu \mathrm{g} / \mathrm{mL}$. Additionally, we can see from the data that the substitution with electron releasing methyl group at the 5- and 6-position of benzimidazole nucleus only result in a little decrease in potency.

Compared to imidazole derivatives, triazole ones 7, 8a and 9a gave weaker antibacterial activities against $S$. aureus, MRSA, B. subtilis, M. luteus, E. coli, $P$. vulgaris, $P$. aeruginosa, $S$. typhi and $S$. dysenteriae with the MIC values ranging from 50 to 400 $\mu \mathrm{g} / \mathrm{mL}$.

Antifungal activities: The antifungal evaluation exhibited that the intermediates 3-5 and most of azole-containing compounds showed antifungal efficacy against $C$. albicans and $S$. cerevisiae to some extent. Unexpectedly, these compounds showed less antifungal activities against $A$. fumigatus, especially triazole ones, which may be due to the intrinsic mechanism resistant to triazole antifungal agents. ${ }^{41}$ Despite of this, title compounds $\mathbf{9 b}$ and $9 \mathbf{e}$ showed desirable antifungal activities against $C$. albicans and $S$. cerevisiae with the MIC values between 3.1 and $12.5 \mu \mathrm{g} /$ $\mathrm{mL}$, which were nearly close to fluconazole being in clinical use. Moreover, the two compounds also displayed excellent activity against $A$. fumigatus (MIC $=25 \mu \mathrm{g} / \mathrm{mL}$ ), which were superior to the first-line antifungal drug fluconazole. This suggested that it is necessary to further investigate compounds $9 \mathbf{b}$ and $9 \mathrm{e}$ as antifungal agents.

In vitro assay for cytotoxic activity: The results of preliminary cytotoxic activity showed that several compounds exhibited low growth inhibition against PC-3 cell line (Figure 2). Compounds 6 and 10a with benzimidazole were found to be most effective 
in vitro against the PC-3 cell line. The former compound 6 reached growth inhibition values $(36.4,60.1$ and $76.5 \%)$ for each tested concentration: $25 \mu \mathrm{M}(10.4 \mu \mathrm{g} / \mathrm{mL}), 50 \mu \mathrm{M}(20.8 \mu \mathrm{g} / \mathrm{mL})$ and $100 \mu \mathrm{M}(41.6 \mu \mathrm{g} / \mathrm{mL})$, and the latter with growth inhibition values $(31.5,54$ and $71.2 \%)$ for each tested concentration: $25 \mu \mathrm{M}$ $(11.1 \mu \mathrm{g} / \mathrm{mL}), 50 \mu \mathrm{M}(22.2 \mu \mathrm{g} / \mathrm{mL})$ and $100 \mu \mathrm{M}(44.4 \mu \mathrm{g} / \mathrm{mL})$. Compounds $\mathbf{8 b}, 9 \mathrm{e}$, and $\mathbf{1 0 b}$ also showed comparative inhibitory activity against PC-3 cell line at the concentration of $100 \mu \mathrm{M}$, with the cell growth inhibition rate of $66.2 \%, 63.5 \%$ and $70.6 \%$ respectively, and compound $\mathbf{1 0 b}$ also could effectively inhibit the cell growth at the mediate dose $(50 \mu \mathrm{M})$. In addition, compounds $8 \mathbf{a}$ and $9 \mathbf{f}$ exhibited moderate inhibitory activity, and the antiproliferative effect achieved at $46.7 \%$ and $42.7 \%$ at the highest dose used. Compared to the good inhibitory activity of above compounds, compounds $9 \mathbf{b}, 9 \mathbf{c}$ and $9 \mathbf{d}$ showed less antiproliferative activity, and compound $9 \mathbf{a}$ with triazole nearly lost the antiproliferative properties. Therefore, it is rational to deduce that the nature of the azole ring exerts an effect on the antiproliferative activity. The presence of benzimidazole group afforded a clear beneficial effect with regard to antiproliferative properties. Meanwhile, the antiproliferative results indicated that all the compounds showed dose-dependent antiproliferative activity in the tested cell line. Further studies are in progress to define the important mechanisms of action of the above mentioned compounds.

\section{Conclusion}

In conclusion, a series of azole-containing piperazine derivatives were designed and synthesized by a convenient and efficient method. All new compounds were characterized by MS, IR, ${ }^{1} \mathrm{H}$ NMR and elemental analyses. The assessment of in vitro antibacterial and antifungal activities which were determined against eight bacterial strains and three fungal strains showed that some intermediates and target compounds exhibited significant antibacterial and antifungal activities, especially imidazole and 2-phenyl imidazole bearing compounds $9 \mathbf{b}$ and $9 \mathbf{e}$ presented better antibacterial and antifungal activities than other compounds against all tested bacterial strains. Moreover, the azole ring had noticeable effect on their antimicrobial efficacy, and imidazoles and benzimidazoles were much more favourable to biological activity than 1,2,4-triazole. These preliminary results suggested that the remarkable and broad-spectrum antibacterial and antifungal efficacy made compounds $9 \mathbf{b}$ and $9 \mathbf{e}$ as promising antimicrobial agents. Further evaluations are necessary on the way to determine the antimicrobial activities of these title compounds in vivo which will help us to optimize these new leading compounds.

On the other hand, compounds $\mathbf{6}$ and $\mathbf{1 0 a}$ with benzimidazole were found to be most effective in vitro against the PC-3 cell line. Further studies are essential to define the important mechanisms of action of the above mentioned compounds and to deduce the structure-activity relationships.

\section{Experimental Section}

General. Melting points were determined on a X-6 melting point apparatus and are uncorrected. Infrared (IR) spectra were recorded on a Bio-Rad FTS-185 (Bio-Rad, Cambridge, MA, USA) by using KBr disks. NMR spectra were recorded by using $\mathrm{CDCl}_{3}$ as solvent and TMS as an internal reference standard on Varian 400 spectrometer or Bruker AV 300 spectrometer. Chemical shifts are reported in parts per million (ppm). Coupling constants $(J)$ are reported in hertz $(\mathrm{Hz})$. The peak shapes are denoted as follows: s, singlet; $d$, doublet; t, triplet; $m$, multiplet, bs, broad singlet. The piperazine was abbreviated as pip. The mass spectra were recorded on FINIGAN TRACE GC/MS. Elemental analyses were carried out on a Carlo Erba model EA 1106 elemental analyzer. TLC analyses were done using precoated silica gel plates. Column chromatographies were performed on silica gel (300 - 400 mesh) column. All chemicals and solvents were of AR grade and, when necessary, were purified and dried by standard methods.

1-(2-Chloroethyl)-4-[(4-chlorophenyl)(phenyl)methyl]piperazine (3): A mixture of 1-((4-chlorophenyl)(phenyl)methyl) piperazine (7.0 g, $24.4 \mathrm{mmol})$, triethylamine (2.828 g, $28 \mathrm{mmol})$ and a large excess of 1,2-dichloroethane was stirred at reflux for $20 \mathrm{~h}$. The progress of the reaction was monitored by TLC. Upon completion, the mixture was filtered to remove the salts. The filtrate was concentrated and then directly purified by chromatographic column (petroleum ether/ethyl acetate, 5/1, v/v) to afford intermediate 3 (2.6 g, 30\% yield) as yellow oil. ${ }^{1} \mathrm{H} \mathrm{NMR}$ $\left(\mathrm{CDCl}_{3}, 400 \mathrm{MHz}\right) \delta$ 7.38-7.18 (m, 9H, Ar-H), 4.25 (s, 1H, $\mathrm{Ar}_{2}-$ $\mathrm{CH}), 3.69\left(\mathrm{t}, J=6.8 \mathrm{~Hz}, 2 \mathrm{H}, \mathrm{ClCH}_{2} \mathrm{CH}_{2}\right), 2.91(\mathrm{t}, J=6.8 \mathrm{~Hz}, 2 \mathrm{H}$, $\mathrm{ClCH}_{2} \mathrm{CH}_{2}$ ), 2.77 (bs, $4 \mathrm{H}$, pip), 2.55 (bs, 4H, pip).

1-Chloro-3-(4-((4-chlorophenyl)(phenyl)methyl)piperazin1-yl)propan-2-ol (4): A mixture of 1-[(4-chlorophenyl)(phenyl) methyl]piperazine $(5.0 \mathrm{~g}, 17.4 \mathrm{mmol})$ and 2-(chloromethyl)oxirane $(4.8 \mathrm{~g}, 52.2 \mathrm{mmol})$ in anhydrous ethanol was stirred at room temperature for $24 \mathrm{~h}$. After the reaction completed (monitored by TLC, eluent, petroleum ether/ethyl acetate, 5/1, v/v), the solvent was removed by a rotary evaporator, and then the mixture was cooled. Distilled water $(30 \mathrm{~mL})$ was added. The resulting solution was extracted with $\mathrm{CH}_{2} \mathrm{Cl}_{2}(30 \mathrm{~mL} \times 3)$. The organic layer was dried over anhydrous $\mathrm{Na}_{2} \mathrm{SO}_{4}$ and then evaporated under reduced pressure. The residue was purified via silica gel column chromatography (petroleum ether/ethyl acetate, 5/1, $\mathrm{v} / \mathrm{v})$ to give compound $4(2.64 \mathrm{~g})$ as white solid. Yield $40 \%$; $\mathrm{mp} 70-72{ }^{\circ} \mathrm{C} ;{ }^{1} \mathrm{H} \mathrm{NMR}\left(\mathrm{CDCl}_{3}, 400 \mathrm{MHz}\right) \delta 7.5-7.35(\mathrm{~m}, 9 \mathrm{H}$, Ar-H), 4.23 (s, 1H, $\left.\mathrm{Ar}_{2} \mathrm{CH}\right), 3.65(\mathrm{~m}, 2 \mathrm{H}), 2.91(\mathrm{~m}, 2 \mathrm{H}), 2.74-$ $2.62(\mathrm{~m}, 8 \mathrm{H}$, pip).

2-Chloro-1-[4-((4-chlorophenyl)(phenyl)methyl)piperazin1-yl]ethanone (5): To a solution of 1-((4-chlorophenyl)(phenyl) methyl)piperazine $(7.0 \mathrm{~g}, 24.4 \mathrm{mmol})$ and triethylamine $(2.828$ $\mathrm{g}, 28 \mathrm{mmol}$ ) in dry dichloromethane at $0{ }^{\circ} \mathrm{C}$ was added 2-chloroacetyl chloride $(6.00 \mathrm{~g}, 53.0 \mathrm{mmol})$ dropwise. The reaction mixture was stirred at $0{ }^{\circ} \mathrm{C}$ about $2 \mathrm{~h}$ and the stirring was continued at room temperature for about $5 \mathrm{~h}$. The progress of the reaction was monitored by TLC. Upon completion, the reaction was quenched with distilled water and extracted with chloroform $(100 \mathrm{~mL} \times 3)$. The organic layer was washed with $10 \%$ ammonium chloride solution and then water and dried over anhydrous $\mathrm{Na}_{2} \mathrm{SO}_{4}$. Chromatographic purification (petroleum ether/ethyl acetate, 4/1, v/v) afforded intermediate 5 (4.0 g, $45 \%$ yield) as yellow oil. ${ }^{1} \mathrm{H} \mathrm{NMR}\left(\mathrm{CDCl}_{3}, 400 \mathrm{MHz}\right) \delta 7.43-$ 7.22 (m, 9H, Ar-H), 4.33 (s, 1H, $\left.\mathrm{Ar}_{2} \mathrm{CH}\right), 4.04$ (s, 2H, $\mathrm{COCH}_{2}$ ), 
3.68 (bs, 2H, pip), 3.58 (bs, 2H, pip), 2.52-2.48 (bs, 4H, pip).

2-((4-((4-Chlorophenyl)(phenyl)methyl)piperazin-1-yl)methyl)-1H-benzo[d]imidazole (6): To a stirred suspension of potassium carbonate $(96 \mathrm{mg}, 0.70 \mathrm{mmol})$ in $5 \mathrm{~mL}$ of acetone was added 1-((4-chlorophenyl)(phenyl)methyl)piperazine (200 mg, $0.70 \mathrm{mmol})$. The mixture was stirred at room temperature for 30 minutes, and then 2-(chloromethyl)- $1 H$-benzo $[d]$ imidazole $(116 \mathrm{mg}, 0.70 \mathrm{mmol})$ was added and the resulting mixture was stirred after $12 \mathrm{~h}$. After the reaction came to the end (monitored by TLC, eluent, ethyl acetate/petroleum ether, 2/1, v/v), the solvent was evaporated. The residue was diluted with water (30 $\mathrm{mL})$, extracted with $\mathrm{CH}_{2} \mathrm{Cl}_{2}(30 \mathrm{~mL} \times 3)$, and the combined organic phase was dried over anhydrous $\mathrm{Na}_{2} \mathrm{SO}_{4}$ and then evaporated under reduced pressure. The product was purified by silica gel column chromatography (ethyl acetate/petroleum ether, 2/1, $\mathrm{v} / \mathrm{v})$ to give the final compound $6(180 \mathrm{mg}, 61 \%$ yield $)$ as yellow solid; mp $109-110{ }^{\circ} \mathrm{C}$; IR (KBr) 3419 (NH), 3085, 3059, 3026, 2956, 2927, 1487, 1453, 1427, 1405, 1134, 745 $\mathrm{cm}^{-1} ;{ }^{1} \mathrm{H}$ NMR $\left(\mathrm{CDCl}_{3}, 400 \mathrm{MHz}\right) \delta 7.57(\mathrm{~s}, 2 \mathrm{H}$, benimidazole$\mathrm{H})$, 7.37-7.19 (m, 11H, Ar-H, benimidazole-H), $4.28(\mathrm{~s}, 1 \mathrm{H}$, $\mathrm{Ar}_{2} \mathrm{CH}$ ), 3.90 (s, 2H, benimidazole- $\mathrm{CH}_{2}$ ), 2.67 (bs, 4H, pip), 2.49 (bs, $4 \mathrm{H}$, pip); ${ }^{13} \mathrm{C} \mathrm{NMR}\left(\mathrm{CDCl}_{3}, 75 \mathrm{MHz}\right) \delta 151.9,141.7$, $140.9,132.7,129.2,128.7,128.6,127.8,127.3,122.5,75.2$, 56.4, 53.7, 51.6; MS (m/z) 417 [M] ${ }^{+}$; Anal. Calcd. for $\mathrm{C}_{25} \mathrm{H}_{25-}$ $\mathrm{ClN}_{4}$ : C, 72.02; H, 6.04; N, 13.44; Found: C, 71.90; H, 5.96; N, 13.31 .

1-(2-(1H-1,2,4-Triazol-1-yl)ethyl)-4-((4-chlorophenyl)(phenyl)methyl)piperazine (7): To a stirred suspension of potassium carbonate $(353 \mathrm{mg}, 2.56 \mathrm{mmol})$ in $10 \mathrm{~mL}$ of acetonitrile was added triazole (177 mg, $2.56 \mathrm{mmol})$. The mixture was stirred at $45^{\circ} \mathrm{C}$ for $1 \mathrm{~h}$. After cooled to room temperature, the compound 3 (891 $\mathrm{mg}, 2.04 \mathrm{mmol})$ was added and the mixture was stirred at $45-70{ }^{\circ} \mathrm{C}$ after $24 \mathrm{~h}$. After the reaction came to the end (monitored by TLC, eluent, chloroform/methanol, 100/1, v/v), the solvent was evaporated and then water $(30 \mathrm{~mL})$ was added. The resulting mixture was extracted with $\mathrm{CH}_{2} \mathrm{Cl}_{2}(30 \mathrm{~mL} \times 3)$, the combined organic phase was dried over anhydrous $\mathrm{Na}_{2} \mathrm{SO}_{4}$ and then evaporated under reduced pressure. The product was purified by silica gel column chromatography (methanol/chloroform, 1/150 - 1/100, v/v) to give the final compound 7 (466 mg, $60 \%$ yield) as yellow oil; IR ( $\mathrm{KBr}) 3146,3027,2941,2881$, $1600,1519,1489,1451,1239,855,757,701 \mathrm{~cm}^{-1} ;{ }^{1} \mathrm{H}$ NMR $\left(\mathrm{CDCl}_{3}, 400 \mathrm{MHz}\right) \delta 8.19(\mathrm{~s}, 1 \mathrm{H}$, triazole $3-\mathrm{H}), 7.91(\mathrm{~s}, 1 \mathrm{H}$, triazole 5-H), 7.36-7.17 (m, 9H, Ar-H), 4.32 (t, $J=6.4 \mathrm{~Hz}, 2 \mathrm{H}$, triazole- $\left.\mathrm{CH}_{2} \mathrm{CH}_{2}\right), 4.20\left(\mathrm{~s}, 1 \mathrm{H}, \mathrm{Ar}_{2} \mathrm{CH}\right), 2.87(\mathrm{t}, J=6.4 \mathrm{~Hz}, 2 \mathrm{H}$, triazole- $\mathrm{CH}_{2} \mathrm{CH}_{2}$ ), 2.56 (s, 4H, pip), 2.42 (s, 4H, pip); $\mathrm{MS}(\mathrm{m} / \mathrm{z})$ $405[\mathrm{M}+\mathrm{Na}]^{+}, 382[\mathrm{M}]^{+}$; Anal. Calcd. for $\mathrm{C}_{21} \mathrm{H}_{24} \mathrm{ClN}_{5}$ : C, 66.04; H, 6.33; N, 18.34; Found: C, 66.14; H, 6.30; N, 18.31.

1-(4-((4-Chlorophenyl)(phenyl)methyl)piperazin-1-yl)-3(1H-1,2,4-triazol-1-yl)propan-2-ol (8a): Compound 8a was prepared according to the procedure reported for 7, starting from triazole (110 mg, $1.6 \mathrm{mmol})$, potassium carbonate $(221 \mathrm{mg}, 1.6$ $\mathrm{mmol}$ ) and compound 4 (529 mg, $1.4 \mathrm{mmol})$. The pure compound 8 a (345 mg, 60\% yield) was obtained as yellow oil after 24 h. IR (KBr) 3417, 3119, 3026, 2941, 2860, 1600, 1540, $1519,1489,1451,1404,1238,854,760,702 \mathrm{~cm}^{-1} ;{ }^{1} \mathrm{H}$ NMR $\left(\mathrm{CDCl}_{3}, 400 \mathrm{MHz}\right) \delta 8.17(\mathrm{~s}, 1 \mathrm{H}$, triazole $3-\mathrm{H}), 7.88(\mathrm{~s}, 1 \mathrm{H}$, triazole 5-H), 7.34-7.14 (m, 9H, Ar-H), 4.29-4.05 (m, 5H), 2.59 (s,
2H), 2.38-2.13 (m, 8H, pip); MS (m/z) 412 [M] $]^{+}$; Anal. Calcd. for $\mathrm{C}_{22} \mathrm{H}_{26} \mathrm{ClN}_{5} \mathrm{O}: \mathrm{C}, 64.15 ; \mathrm{H}, 6.36 ; \mathrm{N}, 17.00$; Found: C, 64.40; $\mathrm{H}, 6.30 ; \mathrm{N}, 16.89$.

1-(4-((4-Chlorophenyl)(phenyl)methyl)piperazin-1-yl)-3(4-nitro-1H-imidazol-1-yl)propan-2-ol (8b): Compound 8b was prepared according to the procedure reported for 7 , starting from 4-nitro-imidazole (147 mg, $1.3 \mathrm{mmol}$ ), potassium carbonate $(179 \mathrm{mg}, 1.3 \mathrm{mmol}$ ) and compound 4 (529 mg, $1.4 \mathrm{mmol})$. The pure compound $\mathbf{8 b}$ (296 $\mathrm{mg}, 50 \%$ yield) was obtained as white solid after $24 \mathrm{~h}$. mp $92-94{ }^{\circ} \mathrm{C}$; IR (KBr) 3417, 3146, 3027, 2941, 2881, 1620, 1543, 1519, 1489, 1451, 1404, 1238, $855,757,701 \mathrm{~cm}^{-1} ;{ }^{1} \mathrm{H} \mathrm{NMR}\left(\mathrm{CDCl}_{3}, 400 \mathrm{MHz}\right) \delta 7.89(\mathrm{~d}, J=$ $1.6 \mathrm{~Hz}, 1 \mathrm{H}$, imidazole $5-\mathrm{H}), 7.45(\mathrm{~d}, J=1.6 \mathrm{~Hz}, 1 \mathrm{H}$, imidazole 2-H), 7.35-7.16 (m, 9H, Ar-H), 4.19 (s, 1H), 4.15-4.11 (m, 1H), 3.97-3.88 (m, 2H), 2.61 (m, 2H), 2.40-2.15 (m, 8H, pip); MS $(\mathrm{m} / z) 478[\mathrm{M}+\mathrm{Na}]^{+}, 456[\mathrm{M}]^{+}$; Anal. Calcd. for $\mathrm{C}_{23} \mathrm{H}_{26} \mathrm{ClN}_{5} \mathrm{O}_{3}$ : C, 60.59; H, 5.75; N, 15.36; Found: C, 60.40; H, 5.68; N, 15.29 .

1-(4-((4-Chlorophenyl)(phenyl)methyl)piperazin-1-yl)-2(1H-1,2,4-triazol-1-yl)ethanone (9a): Compound 9a was prepared according to the procedure reported for 7 , starting from triazole $(110 \mathrm{mg}, 1.6 \mathrm{mmol})$, potassium carbonate $(221 \mathrm{mg}, 1.6$ $\mathrm{mmol}$ ) and compound 5 (471 mg, $1.3 \mathrm{mmol})$. The pure compound $9 \mathbf{a}(308 \mathrm{mg}, 60 \%$ yield) was obtained as white solid after 16 h. mp 112 - $113^{\circ} \mathrm{C}$; IR (KBr) 3119, 3060, 3026, 2960, 2920, 2857, $1661(\mathrm{C}=\mathrm{O}), 1511,1488,1469,1451,1239,851,760,702$ $\mathrm{cm}^{-1}$; ${ }^{1} \mathrm{H} \mathrm{NMR}\left(\mathrm{CDCl}_{3}, 400 \mathrm{MHz}\right) \delta 8.22(\mathrm{~s}, 1 \mathrm{H}$, triazole $3-\mathrm{H})$, $7.94(\mathrm{~s}, 1 \mathrm{H}$, triazole 5-H), 7.36-7.26 (m, 9H, Ar-H), $5.01(\mathrm{~s}, 2 \mathrm{H}$, $\mathrm{COCH}_{2}$ ), 4.23 (s, 1H, $\mathrm{Ar}_{2} \mathrm{CH}$ ), 3.64 (bs, 2H, pip), 3.53 (bs, 2H, pip), 2.40 (bs, 4H, pip); MS (m/z) $418[\mathrm{M}+\mathrm{Na}]^{+}, 396[\mathrm{M}]^{+}$; Anal. Calcd. for $\mathrm{C}_{21} \mathrm{H}_{22} \mathrm{ClN}_{5} \mathrm{O}$ : C, 63.71; H, 5.60; N, 17.69; Found: $\mathrm{C}$, 63.54; H, 5.55; N, 17.55.

1-(4-((4-Chlorophenyl)(phenyl)methyl)piperazin-1-yl)-2(1H-imidazol-1-yl)ethanone (9b): Compound $9 \mathrm{~b}$ was prepared according to the procedure reported for 7 , starting from imidazole (109 mg, $1.6 \mathrm{mmol})$, potassium carbonate $(221 \mathrm{mg}, 1.6$ $\mathrm{mmol}$ ) and compound 5 (471 mg, $1.3 \mathrm{mmol})$. The pure compound $9 \mathrm{~b}$ (380 mg, 74\% yield) was obtained as yellow solid after 48 h. mp: 80 - $81^{\circ} \mathrm{C}$; IR (KBr) 3050, 3027, 2920, 2859, 1660 $(\mathrm{C}=\mathrm{O}), 1540,1490,1452,1426,1408,1238,852,756,701 \mathrm{~cm}^{-1}$; ${ }^{1} \mathrm{H} \mathrm{NMR}\left(\mathrm{CDCl}_{3}, 400 \mathrm{MHz}\right) \delta 7.50(\mathrm{~s}, 1 \mathrm{H}$, imidazole 2-H), 7.357.20 (m, 9H, Ar-H), 7.08 (s, 1H, imidazole 4-H), $6.92(\mathrm{~s}, 1 \mathrm{H}$, imidazole 5-H), 4.74 (s, 2H, $\left.\mathrm{COCH}_{2}\right), 4.24$ (s, 1H, $\left.\mathrm{Ar}_{2} \mathrm{CH}\right), 3.63$ (bs, 2H, pip), 3.44 (bs, 2H, pip), 2.39 (bs, $4 \mathrm{H}$, pip); ${ }^{13} \mathrm{C} \mathrm{NMR}$ $\left(\mathrm{CDCl}_{3}, 75 \mathrm{MHz}\right) \delta 164.4,141.2,140.4,137.8,132.9,131.4$, 129.1, 128.9, 128.8, 127.7, 127.5, 120.2, 75.1, 51.5, 51.2, 48.1, 45.2, 42.4; MS (m/z) $417[\mathrm{M}+\mathrm{Na}]^{+}, 395[\mathrm{M}]^{+}$; Anal. Calcd. for $\mathrm{C}_{22} \mathrm{H}_{23} \mathrm{ClN}_{4} \mathrm{O}: \mathrm{C}, 66.91 ; \mathrm{H}, 5.87$; N, 14.19; Found: C, 66.71; H, $5.82 ; \mathrm{N}, 14.11$.

1-(4-((4-Chlorophenyl)(phenyl)methyl)piperazin-1-yl)-2(4-nitro-1H-imidazol-1-yl)ethanone (9c): Compound 9c was prepared according to the procedure reported for 7 , starting from 4-nitro- $1 H$-imidazole $(147 \mathrm{mg}, 1.3 \mathrm{mmol})$, potassium carbonate (179 mg, $1.3 \mathrm{mmol}$ ) and compound 5 (507 mg, $1.4 \mathrm{mmol})$. The pure compound 9c (404 mg, 71\% yield) was obtained as white solid after 16 h. mp $150-152^{\circ} \mathrm{C}$; IR (KBr) 3061, 3027 , 2961, 2920, 2859, $1661(\mathrm{C}=\mathrm{O}), 1545,1521,1490,1452,1426$, $1408,1238,851,760,702 \mathrm{~cm}^{-1}$; ${ }^{1} \mathrm{H}$ NMR $\left(\mathrm{CDCl}_{3}, 400 \mathrm{MHz}\right)$ $\delta 7.80(\mathrm{~s}, 1 \mathrm{H}$, imidazole 5-H), 7.42 (s, 1H, imidazole 2-H), 7.35- 
7.23 (m, 9H, Ar-H), 4.81 (s, 2H, $\left.\mathrm{COCH}_{2}\right), 4.28$ (s, 1H, $\left.\mathrm{Ar}_{2} \mathrm{CH}\right)$, 3.66 (bs, 2H, pip), 3.48 (bs, 2H, pip), 2.45 (d, $J=14 \mathrm{~Hz}, 4 \mathrm{H}$, pip); MS $(m / z) 462[\mathrm{M}+\mathrm{Na}]^{+}$; Anal. Calcd. for $\mathrm{C}_{22} \mathrm{H}_{22} \mathrm{ClN}_{5} \mathrm{O}_{3}: \mathrm{C}$, 60.07; H, 5.04; N, 15.92; Found: C, 60.21; H, 5.00; N, 15.88.

1-(4-((4-Chlorophenyl)(phenyl)methyl)piperazin-1-yl)-2(2-methyl-4-nitro-1H-imidazol-1-yl)et-hanone (9d): Compound 9d was prepared according to the procedure reported for 7 , starting from 2-methyl-5-nitro- $1 H$-imidazole (165 mg, 1.3 $\mathrm{mmol})$, potassium carbonate $(179 \mathrm{mg}, 1.3 \mathrm{mmol})$ and compound 5 (507 mg, $1.4 \mathrm{mmol}$ ). The pure compound 9d (312 mg, 53\% yield) was obtained as white solid after $16 \mathrm{~h}$. mp $190-192{ }^{\circ} \mathrm{C}$; IR (KBr) 3145, 3061, 3026, 2963, 2925, 2862, $1662(\mathrm{C}=\mathrm{O})$, $1541,1492,1471,1451,1425,1239,835,756,701 \mathrm{~cm}^{-1} ;{ }^{1} \mathrm{H}$ NMR $\left(\mathrm{CDCl}_{3}, 400 \mathrm{MHz}\right) \delta 7.68(\mathrm{~s}, 1 \mathrm{H}$, imidazole 5-H), 7.357.23 (m, 9H, Ar-H), 4.72 (s, 2H, $\left.\mathrm{COCH}_{2}\right), 4.28\left(\mathrm{~s}, 1 \mathrm{H}, \mathrm{Ar}_{2} \mathrm{CH}\right)$, 3.64 (bs, 2H, pip), 3.50 (bs, 2H, pip), 2.47 (bs, 2H, pip), 2.42 (bs, 2H, pip), 2.34 (s, 3H, $\left.\mathrm{CH}_{3}\right)$; $\mathrm{MS}(\mathrm{m} / \mathrm{z}) 476[\mathrm{M}+\mathrm{Na}]^{+}, 454[\mathrm{M}]^{+}$; Anal. Calcd. for $\mathrm{C}_{23} \mathrm{H}_{24} \mathrm{ClN}_{5} \mathrm{O}_{3}$ : C, 60.86; H, 5.33; N, 15.43; Found: C, 60.61; H, 5.29; N, 15.50.

1-(4-((4-Chlorophenyl)(phenyl)methyl)piperazin-1-yl)-2(2-phenyl-1H-imidazol-1-yl)ethanone (9e): Compound 9e was prepared according to the procedure reported for 7 , starting from 2-phenyl-1H-imidazole (187 mg, $1.3 \mathrm{mmol}$ ), potassium carbonate $(179 \mathrm{mg}, 1.3 \mathrm{mmol}$ ) and compound 5 (507 $\mathrm{mg}, 1.4 \mathrm{mmol})$. The pure compound $9 \mathrm{e}$ ( $415 \mathrm{mg}, 68 \%$ yield) was obtained as yellow solid after $48 \mathrm{~h}$. mp $132-134{ }^{\circ} \mathrm{C}$; IR (KBr) 3060, 3027, 2965, 2920, 2859, $1659(\mathrm{C}=\mathrm{O}), 1477,1450,1413,1237,850$, $758,701 \mathrm{~cm}^{-1}$; ${ }^{1} \mathrm{H} \mathrm{NMR}\left(\mathrm{CDCl}_{3}, 400 \mathrm{MHz}\right) \delta 7.48-7.21(\mathrm{~m}, 14 \mathrm{H}$, Ar-H), 7.15 (s, 1H, imidazole 4-H), 7.00 (s, 1H, imidazole 5-H), 4.71 (s, 2H, $\left.\mathrm{COCH}_{2}\right), 4.23$ (s, 1H, $\left.\mathrm{Ar}_{2} \mathrm{CH}\right), 3.64$ (bs, 2H, pip), 3.28 (bs, 2H, pip), 2.37 (bs, 2H, pip), 2.27 (bs, $2 \mathrm{H}$, pip); ${ }^{13} \mathrm{C}$ NMR $\left(\mathrm{CDCl}_{3}, 75 \mathrm{MHz}\right) \delta 164.9,148.0,141.1,140.3,133.0$, 129.1, 128.9, 128.8, 128.7, 128.5, 127.7, 127.5, 122.0, 98.4, 75.0, 51.6, 51.3, 48.0, 45.1, 42.5; MS (m/z) $471\left[\mathrm{M}^{+}\right.$; Anal. Calcd. for $\mathrm{C}_{28} \mathrm{H}_{27} \mathrm{ClN}_{4} \mathrm{O}$ : C, 71.40; H, 5.78; N, 11.90; Found: C, $71.23 ; \mathrm{H}, 5.26 ; \mathrm{N}, 15.45$.

1-(4-((4-Chlorophenyl)(phenyl)methyl)piperazin-1-yl)-2(2-methyl-1H-imidazol-1-yl)ethanone (9f): Compound 9 f was prepared according to the procedure reported for 7 , starting from 2-methyl-1H-imidazole (131 mg, $1.6 \mathrm{mmol})$, potassium carbonate $(221 \mathrm{mg}, 1.6 \mathrm{mmol})$ and compound 5 (471 $\mathrm{mg}, 1.3 \mathrm{mmol})$. The pure compound 9 f ( $263 \mathrm{mg}, 50 \%$ yield) was obtained as yellow solid after 48 h. mp $115-116^{\circ} \mathrm{C}$; IR (KBr) 3027, 2964, 2922, 2859, $1657(\mathrm{C}=\mathrm{O}), 1531,1487,1471,1422,1237,837$, $759,701 \mathrm{~cm}^{-1}$; ${ }^{1} \mathrm{H} \mathrm{NMR}\left(\mathrm{CDCl}_{3}, 400 \mathrm{MHz}\right) \delta 7.35-7.21(\mathrm{~m}, 9 \mathrm{H}$, Ar-H), 6.90 (s, 1H, imidazole 4-H), 6.76 (s, 1H, imidazole 5-H), 4.60 (s, 2H, $\left.\mathrm{COCH}_{2}\right), 4.23$ (s, 1H, $\left.\mathrm{Ar}_{2} \mathrm{CH}\right), 3.62$ (bs, 2H, pip), 3.44 (bs, $2 \mathrm{H}$, pip), 2.38 (bs, $4 \mathrm{H}$, pip), 2.29 (s, 3H, $\mathrm{CH}_{3}$ ); MS $(\mathrm{m} / \mathrm{z}) 431[\mathrm{M}+\mathrm{Na}]^{+}, 409[\mathrm{M}]^{+}$; Anal. Calcd. for $\mathrm{C}_{23} \mathrm{H}_{25} \mathrm{ClN}_{4} \mathrm{O}$ : C, 67.55; H, 6.16; N, 13.70; Found: C, 67.32; H, 5.22; N, 15.39.

2-(1H-Benzo $[d]$ imidazol-1-yl)-1-(4-((4-chlorophenyl)(phenyl)methyl)piperazin-1-yl)ethanone (10a): Compound 10a was prepared according to the procedure reported for 7 , starting from benzimidazole (153 mg, $1.3 \mathrm{mmol})$, potassium carbonate (179 mg, $1.3 \mathrm{mmol}$ ) and compound 5 (507 mg, $1.4 \mathrm{mmol})$. The pure compound 10a (226 mg, 39\% yield) was obtained as yellow solid after 48 h. mp $156-157^{\circ} \mathrm{C}$; IR (KBr) 3059, 3027, 2967, 2921, 2860, $1658(\mathrm{C}=\mathrm{O}), 1495,1457,1423,1238,850,744,702$ $\mathrm{cm}^{-1} ;{ }^{1} \mathrm{H} \mathrm{NMR}\left(\mathrm{CDCl}_{3}, 400 \mathrm{MHz}\right) \delta 7.90(\mathrm{~s}, 1 \mathrm{H}$, benzimidazole 2-H), 7.80 (s, 1H, benzimidazole 4-H), 7.34-7.22 (m, 12H, Ar$\mathrm{H}), 4.92$ (s, 2H, $\left.\mathrm{COCH}_{2}\right), 4.24$ (s, 1H, $\left.\mathrm{Ar}_{2} \mathrm{CH}\right), 3.65$ (bs, 2H, pip), 3.52 (bs, $2 \mathrm{H}$, pip), 2.40 (bs, $4 \mathrm{H}$, pip); ${ }^{13} \mathrm{CNMR}\left(\mathrm{CDCl}_{3}, 75 \mathrm{MHz}\right)$ $\delta 164.3,143.7,141.3,140.5,133.1,129.2,129.0,128.9,127.8$, 127.6, 123.3, 122.4, 120.5, 109.4, 75.1, 51.7, 51.3, 45.9, 45.4, 42.6; MS (m/z) $445[\mathrm{M}]^{+}$; Anal. Calcd. for $\mathrm{C}_{26} \mathrm{H}_{25} \mathrm{ClN}_{4} \mathrm{O}: \mathrm{C}$, 70.18; H, 5.66; N, 12.59; Found: C, 70.35; H, 5.72; N, 12.55.

1-(4-((4-Chlorophenyl)(phenyl)methyl)piperazin-1-yl)-2(5,6-dimethyl-1H-benzo[d] imidazol-1-yl)ethanone (10b): Compound $10 \mathrm{~b}$ was prepared according to the procedure reported for 7, starting from benzimidazole (190 mg, $1.3 \mathrm{mmol})$, potassium carbonate (179 mg, $1.3 \mathrm{mmol}$ ) and compound 5 (507 mg, $1.4 \mathrm{mmol})$. The pure compound $\mathbf{1 0 b}(166 \mathrm{mg}, 27 \%$ yield $)$ was obtained as yellow solid after $48 \mathrm{~h}$. mp $200-201{ }^{\circ} \mathrm{C}$; IR (KBr) 3059, 3027, 2967, 2921, 2860, 2680, 1659 (C=O), 1495, 1457, $1423,1238,852,750,702 \mathrm{~cm}^{-1} ;{ }^{1} \mathrm{H} \mathrm{NMR}\left(\mathrm{CDCl}_{3}, 400 \mathrm{MHz}\right) \delta$ 7.77 (s, $1 \mathrm{H}$, benzimidazole-H), 7.55 (s, 1H, benzimidazole- $\mathrm{H})$, 7.34-7.22 (m, 9H, Ar-H), 7.04 (s, 1H, benzimidazole-H), 4.86 (s, $2 \mathrm{H}, \mathrm{COCH}_{2}$ ), 4.23 (s, $1 \mathrm{H}, \mathrm{Ar}_{2} \mathrm{CH}$ ), 3.65 (bs, 2H, pip), 3.49 (bs, 2H, pip), 2.39 (bs, 4H, pip), 2.35 (s, 6H, $\left.\mathrm{CH}_{3}\right)$; MS ( $\left.\mathrm{m} / \mathrm{z}\right) 473$ $[\mathrm{M}]^{+}$; Anal. Calcd. for $\mathrm{C}_{28} \mathrm{H}_{29} \mathrm{ClN}_{4} \mathrm{O}$ : C, 71.10; H, 6.18; N, 11.84; Found: C, 70.90; H, 6.12; N, 12.00 .

2-(1H-Benzo[d][1,2,3]triazol-1-yl)-1-(4-((4-chlorophenyl)(phenyl)methyl)piperazin-1-yl)ethanone (10c): Compound 10c was prepared according to the procedure reported for 7 , starting from benzotriazole $(155 \mathrm{mg}, 1.3 \mathrm{mmol})$, potassium carbonate (179 mg, $1.3 \mathrm{mmol}$ ) and compound 5 (507 mg, $1.4 \mathrm{mmol})$. The pure compound 10c (465 mg, 80\% yield) was obtained as white solid after 48 h. mp $189-190{ }^{\circ} \mathrm{C}$; IR (KBr) 3166, 3061, 3026, 2962, 2921, 2858, 1632 (C=O), 1448, 1439, 1403, 1224, 849, $758,701 \mathrm{~cm}^{-1} ;{ }^{1} \mathrm{H} \mathrm{NMR}\left(\mathrm{CDCl}_{3}, 400 \mathrm{MHz}\right) \delta 7.51-7.49(\mathrm{~m}, 2 \mathrm{H}$, benzotriazole-H), 7.35-7.17 (m, 11H, Ar-H, benzotriazole-H), 4.24 (s, $\left.1 \mathrm{H}, \mathrm{Ar}_{2} \mathrm{CH}\right), 3.96$ (s, 2H, $\left.\mathrm{COCH}_{2}\right), 3.71$ (bs, 2H, pip), 3.60 (bs, 2H, pip), 2.45 (d, $J=23.2 \mathrm{~Hz}, 4 \mathrm{H}$, pip); MS (m/z) 468 $[\mathrm{M}+\mathrm{Na}]^{+}, 446[\mathrm{M}]^{+}$; Anal. Calcd. for $\mathrm{C}_{25} \mathrm{H}_{24} \mathrm{ClN}{ }_{5} \mathrm{O}$ : C, 67.33; H, 5.42; N, 15.70; Found: C, 67.60; H, 5.38; N, 15.60.

2-(1H-Benzo[d] imidazol-2-ylthio)-1-(4-((4-chlorophenyl) (phenyl)methyl)piperazin-1-yl)ethanone (11): Compound 11 was prepared according to the procedure reported for 7 , starting from $1 H$-benzo[ $d$ ] imidazole-2-thiol $(127 \mathrm{mg}, 0.847 \mathrm{mmol})$, potassium carbonate $(179 \mathrm{mg}, 1.3 \mathrm{mmol})$ and compound $\mathbf{5}$ (217 $\mathrm{mg}, 0.598 \mathrm{mmol})$. The pure compound 11 (268 $\mathrm{mg}, 85 \%$ yield $)$ was obtained as white solid after $48 \mathrm{~h}$. mp $185-187^{\circ} \mathrm{C}$; IR (KBr) 3425(NH), 3063, 3027, 2959, 2923, 2861, $1662(\mathrm{C}=\mathrm{O}), 1454$, $1405,1234,850,747,701 \mathrm{~cm}^{-1} ;{ }^{1} \mathrm{H} \mathrm{NMR}\left(\mathrm{CDCl}_{3}, 400 \mathrm{MHz}\right)$ $\delta 8.04(\mathrm{~d}, J=8.0 \mathrm{~Hz}, 1 \mathrm{H}$, benzimidazole-H), $7.56(\mathrm{~d}, J=8.0$ $\mathrm{Hz}, 1 \mathrm{H}$, benzimidazole- $\mathrm{H}), 7.48(\mathrm{t}, J=8.0 \mathrm{~Hz}, 1 \mathrm{H}$, benzimidazole-H), 7.38-7.20 (m, 10H, benzimidazole-H, Ar- $H$ ), 5.46 (s, 2H, $\left.\mathrm{COCH}_{2}\right), 4.19$ (s, 1H, $\left.\mathrm{Ar}_{2} \mathrm{CH}\right), 3.61$ (bs, 4H, pip), 2.33 (m, 4H, pip); $\mathrm{MS}(\mathrm{m} / \mathrm{z}) 477[\mathrm{M}]^{+}$. Anal. Calcd. for $\mathrm{C}_{26} \mathrm{H}_{25} \mathrm{ClN}_{4-}$ OS: C, 65.46; H, 5.28; N, 11.75; Found: C, 65.24; H, 5.20; N, 11.62 .

Antibacterial and antifungal assays. The in vitro minimal inhibitory concentrations (MICs) of the compounds 3-11 were determined by the twofold broth dilution method against Grampositive bacteria (Staphylococcus aureus ATCC 25923, Methicillin-resistant Staphylococcus aureus N315 (MRSA), Bacillus 
subtilis ATCC 6633 and Micrococcus luteus ATCC 4698), Gram-negative bacteria (Escherichia coli ATCC 25922, Proteus vulgaris ATCC 6896, Salmonella typhi ATCC 9484 and Shigella dysenteriae) and fungi (Candida albicans ATCC 76615; Saccharomyces cerevisiae ATCC 9763 and Aspergillus fumigatus ATCC) 96918. The minimal inhibitory concentration (MIC, $\mu$ $\mathrm{g} / \mathrm{mL}$ ) was defined as the lowest concentration of compounds that completely inhibited the growth of each strain. ${ }^{36}$ Antibacterial drug chloramphenicol and antifungal drug fluconazole were used as standard drugs. Test compounds were dissolved in $\mathrm{H}_{2} \mathrm{O}$ containing $1 \%$ DMSO and diluted into different concentrations from 0.8 to $400 \mu \mathrm{g} / \mathrm{mL}$ with liquid medium. The bacterial inocula was at the concentration of $1 \times 10^{5} \mathrm{CFU}$, and the fungi spore $1-5 \times 10^{3}$ spore $/ \mathrm{mL}$. These dilutions were inoculated and incubated at $37^{\circ} \mathrm{C}$ for $24 \mathrm{~h}$ for bacteria in Mueller-Hinton broth and at $30{ }^{\circ} \mathrm{C}$ for $48 \mathrm{~h}$ for the fungi in improved Sabourasud medium. Microbial growth was monitored visually and spectrophotometrically. The $\mathrm{H}_{2} \mathrm{O} / 1 \%$ DMSO was used as a blank, inoculation bacterial not medicine as positive control. All experiments were performed in triplicate.

MTT assay for cytotoxic activity. The human prostatic carcinoma cell line (PC-3) was purchased from the Shanghai Institutes for Biological Sciences, China. Ham's F12 Nutrient Mixture, enriched with $10 \%$ heat inactivated foetal bovine serum (FBS) and $1 \%$ of penicillin-streptomycin was used for cell cultivation and to perform the tests. The cytotoxic activity was investigated using the MTT assay (3-(4,5-dimethylthiazole-2yl)-2,5-diphenyltetrazolium bromide). ${ }^{26}$ Stock solutions (100 $\mathrm{mM}$ ) of tested compounds $\mathbf{6 , 8}, \mathbf{a}-\mathbf{b}, \mathbf{9}, \mathbf{a}-\mathbf{f}$ and $\mathbf{1 0 a}-\mathbf{b}$ were prepared in dimethylsulfoxide (DMSO) and stored at $-20{ }^{\circ} \mathrm{C}$ prior to dilution into the biological assay. Cell suspensions were diluted to $10^{5}$ cells $/ \mathrm{mL}$, suitably prepared and distributed in plates of culture with 96 wells $\left(225 \mu \mathrm{L}\right.$ in each well), then incubated at $37{ }^{\circ} \mathrm{C}$ in a humid atmosphere with $5 \%$ of $\mathrm{CO}_{2}$. After $24 \mathrm{~h}, 25 \mu \mathrm{L}$ of the test compounds were added to each well. The plates were incubated again at $37^{\circ} \mathrm{C}$ for $24 \mathrm{~h}$. Then, $25 \mu \mathrm{L}$ of MTT solution $(5$ $\mathrm{mg} / \mathrm{mL}$ ) was added to each well, and the mixture was incubated at $37{ }^{\circ} \mathrm{C}$ for $2 \mathrm{~h}$. At the end of this period, the culture medium with the MTT excess was aspirated and after that, $100 \mu \mathrm{L}$ of DMSO was added to each well to dissolve the formazan crystals. The optical density (OD) of the wells was measured at $490 \mathrm{~nm}$. Results were evaluated by comparing the absorbance of the wells containing compound treated cells with the absorbance of wells containing $0.1 \%$ DMSO alone (solvent control). Conventionally, cell viability was estimated to be $100 \%$ in the solvent control. All assays were performed in triplicate and mean \pm SD values were used to estimate cell growth inhibition rate.

Acknowledgments. This work was partially supported by Natural Science Foundation of Chongqing (CSCT: 2007BB5369, 2009BB5296) and Southwest University (SWUB2006018, XSGX0602).

\section{References}

1. Sojakova, M.; Liptajova, D.; Borovsky, M. Mycopathologia 2004, 157, 163-169.

2. Lyman, C. A.; Walsh, T. J. Drugs 1992, 44, 9-35.

3. Phillips O. A.; Udo E. E.; Samuel S. M. Eur. J. Med. Chem. 2008,
$43,1095-1104$

4. Foye, W. O.; Lemke, T. L.; William, D. A. Principles of Medicinal Chemistry, 4th ed.; Williams and Wilkins: London, 1995.

5. (a) Gan, L. L.; Lu, Y. H.; Zhou, C. H. Chin. J. Biochem. Pharma. 2009, 30, 127-131. (b) Cai, J. L.; Lu, Y. H.; Gan, L. L.; Zhou, C. H. Chin. J. Antibiotics. 2009, 34, 454-462 (in Chinese); (c) Gan, L. L.; Cai, J. L.; Zhou, C. H. Chin. Pharma. J. 2009, 44, 1361-1368 (in Chinese).

6. Foroumadi, A.; Emami, S.; Mansouri, S.; Javidnia, A.; Saeid-Adeli, N.; Shirazi, F. H.; Shafiee, A. Eur. J. Med. Chem. 2007, 42, 985992.

7. Lohray, B. B.; Lohray, V. B.; Srivastava, B. K.; Gupta, S.; Solanki, M.; Pandya, P.; Kapadnis, P. Bioorg. Med. Chem. Lett. 2006, 16, $1557-1561$.

8. Foroumadi, A.; Ghodsi, S.; Emami, S.; Najjari, S.; Samadi, N.; Faramarzi, M. A.; Beikmohammadi, L.; Shirazi, F. H.; Shafiee, A. Bioorg. Med. Chem. Lett. 2006, 16, 3499-3503.

9. Watkins, W. J.; Chong, L.; Cho, A.; Hilgenkamp, R.; Ludwikow, M.; Garizi, N.; Iqbal, N.; Barnard, J.; Singh, R.; Madsen, D.; Lolans, K.; Lomovskaya, O.; Oza, U.; Kumaraswamy, P.; Blecken, A.; Bai, S.; Loury, D. J.; Griffitha, D. C.; Dudley, M. N. Bioorg. Med. Chem. Lett. 2007, 17, 2802-2806.

10. Upadhayaya, R. S.; Sinha, N.; Jain, S.; Kishore, N.; Chandra, R.; Arora, S. K. Bioorg. Med. Chem. 2004, 12, 2225-2238.

11. Rokosz, L. L.; Huang, C. Y.; Reader, J. C.; Stauffer, T. M.; Chelsky, D.; Sigal, N. H.; Ganguly, A. K.; Baldwin, J. J. Bioorg. Med. Chem. Lett. 2005, 15, 5537-5543.

12. Chen, J. J.; Lu, M.; Jing, Y. K.; Dong, J. H. Bioorg. Med. Chem. 2006, 14, 6539-6547.

13. Shami, P. J.; Saavedra, J. E.; Bonifant, C. L.; Chu, J. X.; Udupi, V.; Malaviya, S.; Carr, B. I.; Kar, S.; Wang, M. F.; Jia, L.; Ji, X. H.; Keefer, L. K. J. Med. Chem. 2006, 49, 4356-4366.

14. Mayence, A.; Eynde, J. J. V.; LeCour, L.; Jr Walker, L. A.; Tekwani, B. L.; Huang, T. L. Eur. J. Med. Chem. 2004, 39, 547-553.

15. Cunico, W.; Gomes, C. R. B.; Moreth, M.; Manhanini, D. P.; Figueiredo, I. H.; Penido, C.; Henriques, M. G. M. O.; Varotti, F. P.; Krettli, A. U. Eur. J. Med. Chem. 2009, 44, 1363-1368.

16. Smits, R. A.; Lim, H. D.; Hanzer, A.; Zuiderveld, O. P.; Guaita, E.; Adami, M.; Coruzzi, G.; Leurs, R.; Esch, I. J. P. J. Med. Chem. 2008, 51, 2457-2467.

17. Penjišević, J.; Šukalović, V.; Andrić, D.; Kostić-Rajačić, S.; Šoškić, V.; Roglić, G. Arch. Pharm. Chem. Life Sci. 2007, 340, 456465 .

18. Becker, O. M.; Dhanoa, D. S.; Marantz, Y.; Chen, D.; Shacham, S.; Cheruku, S.; Heifetz, A.; Mohanty, P.; Fichman, M.; Sharadendu, A.; Nudelman, R.; Kauffman, M.; Noiman, S. J. Med. Chem. 2006, 49, 3116-3135.

19. Bean, D. C.; Wareham, D. W. J. Antimicrobl. Chemother. 2009, 63, 349-352.

20. Coban, A. Y.; Bayram, Z.; Sezgin, F. M.; Durupinar, B. Mikrobiyoloji. Bulteni. 2009, 43, 457-461.

21. Chaudhary, P.; Kumar, R.; Verma, A. K.; Singh, D.; Yadav, V.; Chhillar, A. K.; Sharmab, G. L.; Chandraa, R. Bioorg. Med. Chem. 2006, 14, 1819-1826.

22. Farzaliev, V. M.; Abbasova, M. T.; Ashurova, A. A.; Babaeva, G. B.; Ladokhina, N. P.; Kerimova, Y. M. Russian J. Appl. Chem. 2009, 82, 928-930.

23. Weiderhold, K. N.; Randall-Hlubek, D. A.; Polin, L. A.; Hamel, E.; Mooberry, S. L. Int. J. Cancer 2006, 118, 1032-1040.

24. Senthilkumar, P.; Dinakaran, M.; Banerjee, D.; Devakaram, R. V.; Yogeeswari, P.; China, A.; Nagaraja, V.; Sriram, D. Bioorg. Med. Chem. 2008, 16, 2558-2569.

25. Narendra Sharath Chandra, J. N.; Sadashiva, C. T.; Kavitha, C. V.; Rangappa, K. S. Bioorg. Med. Chem. 2006, 14, 6621-6627.

26. Ananda Kumar, C. S.; Benaka Prasad, S. B.; Vinaya, K.; Chandrappa, S.; Thimmegowda, N. R.; Sunil Kumar, Y. C.; Sanjay, S.; Rangappa, K. S. Eur. J. Med. Chem. 2009, 44, 1223-1229.

27. Huang, S. L.; Lin, R. H.; Yu, Y.; Lu, Y. H.; Connolly, P. J.; Chiu, 
G.; Li, S. J.; Emanuel, S. L.; Middleton, S. A. Bioorg. Med. Chem. Lett. 2007, 17, 1243-1245.

28. Bellina, F.; Cauteruccio S.; Monti, S.; Rossi, R. Bioorg. Med. Chem. Lett. 2006, 16, 5757-5762.

29. Wu, J.; Mi, J. L.; Zhou, C. H. Chin. Pharm. J. 2007, 46, 404-409 (in Chinese)

30. Güven, Ö. Ö.; Erdoğan, T.; Göker, H.; Yıldız, S. Bioorg. Med. Chem. Lett. 2007, 17, 2233-2236.

31. Mi, J. L.; Wu, J.; Zhou, C. H. West China J. Pharm. Sci. 2008, $23,84-86$ (in Chinese).

32. Zhou, C. H.; Hassner, A. Carbohydrates Res. 2001, 333, 313-326.

33. Cai, J. L.; Li, S.; Zhou, C. H.; Gan, L. L.; Wu, J. Chin. J. New Drugs 2009, 18, 598-608 (in Chinese).

34. Luo, Y.; Lu, Y. H.; Gan, L. L.; Zhou, C. H.; Wu, J.; Geng, R. X.; Zhang, Y. Y. Arch. Pharm. Chem. Life Sci. 2009, 342, 386-393.
35. Zhang, F. F.; Gan ,L. L.; Zhou, C. H. Bioorg. Med. Chem. Lett. 2010, 20, 1881-1884.

36. Ren, F. K.; He, X. Y.; Deng, F.; Li, B. H.; Shin, D. S.; Li, Z. B. Bull. Korean Chem. Soc. 2009, 30, 687-690.

37. Hamied, Y. K.; Kulkarni, V. M. WO 2001079188, 2001.

38. (a) Press, J. B.; Hajos, Z. EP 0331510, 1989; (b) Press, J. B.; Falotico, R.; Hajos, Z. G.; Sawyers, R. A.; Kanojia, R. M.; Williams, L.; Haertlein, B.; Kauffman, J. A.; Lakas-Weiss, C.; Salata, J. J. J. Med. Chem. 1992, 35, 4509-4515.

39. Wright, H. B.; Martin, D. L. J. Med. Chem. 1968, 11, 390-391.

40. McCalmont, W. F.; Heady, T. N.; Patterson, J. R.; Lindenmuth, M. A.; Haverstick, D. M.; Gray, L. S.; Macdonald, T. L. Bioorg. Med. Chem. Lett. 2004, 14, 3691-3695.

41. Chai, X. Y.; Zhang, J.; Hu, H. G.; Yu, S. C.; Sun, Q. Y.; Dan, Z. G.; Jiang, Y. Y.; Wu, Q. Y. Eur. J. Med. Chem. 2009, 44, 1913-1920. 